DOI: 10.32786/2071-9485-2021-02-22

\title{
AGROCHEMICAL AND ECONOMIC ASSESSMENT OF THE USE MINERAL FERTILIZERZ APPLICATION AND RIZOTORFIN ON THE SOYBEAN VARIETIES OF DIFFERENT RIPENESS GROUPS UNDER IRRIGATION CONDITIONS
}

\author{
O. G. Shabaldas ${ }^{1}$, K. I. Pimonov ${ }^{2}$, A. N. Yesaulko ${ }^{1}$, \\ V. V. Borodychev ${ }^{3}$, S. S. Vaitsekhovskaya ${ }^{1}$ \\ ${ }^{I}$ Federal State Budget Educational Institution of Higher Education \\ "Stavropol State Agrarian University», Stavropol \\ ${ }^{2}$ Federal State Budget Educational Institution of Higher Education \\ "Don State Agrarian University», Rostov \\ ${ }^{3}$ Volgograd Branch of the All-Russian Research Institute for Hydraulic Engineering \\ and Land Reclamation, Volgograd
}

Received 11.01.2021

Submitted 20.05.2021

\section{Summary}

The results of research on the use of mineral fertilizers and biological products in the cultivation of soybean varieties belonging to different groups of ripeness under irrigation in the zone of unstable moisture in the Stavropol Territory are presented. On ordinary chernozem, a positive effect was obtained from the combination of the introduction of ammophos under the main treatment at a dose of $\mathrm{N}_{24} \mathrm{P}_{104}$ and inoculation of seeds with rhizotorphin in the cultivation of precocious, early-maturing and medium-maturing soybean varieties.

Abstract
Introduction.In recent years, in the whole world, including in the Russian Federation, there has been an increased demand in the field of soybean grain production due to the fact that this crop is one of the leading sources of vegetable protein and fat, which serve as raw materials for the food, feed and processing industries. Soy is grown in more than 60 countries around the world. In Russia, 4.6 million tons were harvested in 2019, which secured the 8th place among the countries of the world that grow this crop. The growth of the gross soybean grain harvest is currently mainly due to an increase in the area of its sowing, over the past 10 years, its average annual growth is $13.4 \%$, the yield on average in the country remains quite low- 1.57 t/ha. In this regard, it is possible to ensure a stable yield of high-quality soybean grain by improving the elements of cultivation technology, and, in particular, optimizing mineral nutrition in irrigation conditions. In the Stavropol Territory, the possibility of optimizing mineral nutrition with macronutrients $(\mathrm{N}, \mathrm{P}, \mathrm{K})$ through the use of mineral fertilizers in the cultivation of soybean varieties of different maturity groups has not been studied. The purpose of the research is to increase the yield and quality of grain by applying mineral fertilizers and biological products in the cultivation of soybean varieties belonging to different groups of ripeness. Material and methods. The research was carried out in 2008-2010 on ordinary chernozem in the zone of unstable moistening of the Stavropol Territory. The objects of research were doses of mineral fertilizers and a biological product (rizotorfin), soybean varieties of various maturity groups. When conducting field and laboratory studies, the yield and quality of grain were determined, and the economic efficiency of the studied agricultural practices was calculated. Harvesting of soybean grain was carried out with a Sampo 500 combine harvester. The field and laboratory studies were carried out in accordance with the generally accepted methods: B. A. Dospekhov (1985), F. A. Yudin (1980), V. N. Pleshakov (1983). To determine the content of protein and vegetable fat in soy grain, a nuclear magnetic analyzer AMB-1006 M and an IR analyzer MATRIX-I were used. The economic efficiency of the studied agricultural practices is calculated using technological maps for the cultivation of agricultural crops. Results and discussion. Studies conducted in the conditions of field experience, in the zone of unstable moisture during irrigation, showed that a significant increase in grain yield was obtained when growing soybean varieties of different maturity groups, on variants with the introduction of ammophos for the main tillage in doses of $\mathrm{N}_{12} \mathrm{P}_{52}$ and $\mathrm{N}_{24} \mathrm{P}_{104}-0.13-0.26$, and when combined with the introduction of ammophos for the main tillage in doses of $\mathrm{N}_{12} \mathrm{P}_{52}$ and $\mathrm{N}_{24} \mathrm{P}_{104}$ and inoculation of seeds with rhizotorphin, it was the greatest $-0.19-0.33 \mathrm{t} / \mathrm{ha}$. The use of the biological preparation allowed to increase the protein content in the grain by $0.5-0.8 \%$. Early-and 
mid-ripened soybean varieties responded positively to the use of ammophos in doses of $\mathrm{N}_{12} \mathrm{P}_{52}$ and $\mathrm{N}_{24} \mathrm{P}_{104}$ in combination with inoculation of seeds with rhizotorphin, the protein content increased by $0.7-1.3 \%$. The applied agricultural methods did not affect the content of vegetable fat in soybean grain. The maximum grain yield of $2.74 \mathrm{t} / \mathrm{ha}$, as well as the collection of protein $-0.92 \mathrm{t} / \mathrm{ha}$ and vegetable fat $-0.54 \mathrm{t} / \mathrm{ha}$ were obtained with the combined use of ammophos at a dose of $\mathrm{N}_{24} \mathrm{P}_{104}$ and rhizotorphin on the variant with the cultivation of the medium-ripe soybean variety Select 302. The use of ammophos in doses of $\mathrm{N}_{12} \mathrm{P}_{52}$ and $\mathrm{N}_{24} \mathrm{P}_{104}$ for basic tillage, both independently and in combination with a bacterial preparation, is economically justified. The best economic indicators were obtained on the variant with the cultivation of the Selecta 302 variety and the introduction of ammophos at a dose of $\mathrm{N}_{12} \mathrm{P}_{52}$ in combination with inoculation before sowing seeds with rhizotorphin, the profitability was $68.8 \%$. Conclusions. In the conditions of the zone of unstable moisture on ordinary chernozem, a positive effect was obtained from the combination of the introduction of ammophos under the main treatment in doses of $\mathrm{N}_{12} \mathrm{P}_{52}$ and $\mathrm{N}_{24} \mathrm{P}_{104}$ and inoculation of seeds with rhizotorphin when growing precocious, early-ripening and medium-ripening soybean varieties under irrigation. The highest yield of $2.74 \mathrm{t} / \mathrm{ha}$ was obtained when applying ammophos at a dose of $\mathrm{N}_{24} \mathrm{P}_{104}$ and treating seeds with rhizotorphin, when growing the medium-ripe variety Selecta 302 . The best economic effect - $68.8 \%$ - was obtained when cultivating the Selecta 302 variety with the introduction of ammophos at a dose of $\mathrm{N}_{12} \mathrm{P}_{52}$ and inoculation of seeds with rhizotorphin.

Key words: soybean crop, fertilizer, bacterial preparation, variety, ripeness group, yield, protein, vegetable fat, economic assessment.

Citation. Shabaldas O. G., Pimonov K. I., Esaulko A. N., Borodychev V. V., Vaytsekhovskaya S. S. Agrochemical and economic assessment of the use of mineral fertilizers and rizotorfin on the soybean varieties of different ripeness groups under irrigation conditions. Proc. of the Lower Volga AgroUniversity Comp. 2021. 2(62). 209-222 (in Russian). DOI: 10.32786/2071-9485-2021-02-22.

Author's contribution. All authors of this research paper have directly participated in the planning, execution, or analysis of this study. All authors of this paper have read and approved the final version submitted.

Conflict of interest. The authors declare no conflict of interest.

УДК633.34:631.8:631.445.41:338.43

\section{АГРОХИМИЧЕСКАЯ И ЭКОНОМИЧЕСКАЯ ОЦЕНКА ПРИМЕНЕНИЯ МИНЕРАЛЬНЫХ УДОБРЕНИЙ И РИЗОТОРФИНА НА СОРТАХ СОИ РАЗЛИЧНЫХ ГРУПП СПЕЛОСТИ В УСЛОВИЯХ ОРОШЕНИЯ}

О.Г. Шабалдас ${ }^{1}$, кандидат сельскохозяйственных наук, доиент

К.И. Пимонов ${ }^{2}$, доктор сельскохозяйственных наук, профессор

А.Н. Есаулко ${ }^{1}$, доктор сельскохозяйственных наук, профессор, профессор РАН

В.В. Бородычев ${ }^{3}$, доктор сельскохозяйственных наук, профессор, академик РАН

С.С. Вайцеховская ${ }^{1}$, кандидат экономических наук, доцент

${ }^{I}$ Федеральное государственное бюджетное образовательное учреждение

высшего образования "Ставропольский государственный аграрный университет», 2. Ставрополь, Россия

${ }^{2}$ Федеральное государственное бюджетное образовательное учреждение выстего образования «Донской государственный аграрный университет», n. Персиановский,

Ростовская область, Россия

${ }^{3}$ Волгоградский филиал Всероссийский НИИ гидротехники и мелиорации имени А.Н. Костякова, г. Волгоград, Россия

Received 11.01.2021

Submitted 20.05.2021

Актуальность.В последние годы в целом в мире, в том числе и в Российской Федерации, отмечается повышенный спрос в области производства зерна сои в связи с тем, что эта культура является одним из ведущих источников растительного белка и жира, которые служат сырьем для пищевой, кормовой и перерабатывающей промышленности. Соя выращивается более чем в 60 
странах мира. В России в 2019 году было собрано 4,6 млн тонн, что обеспечило 8 место среди стран мира, выращивающих эту культуру. Рост валового сбора зерна сои происходит в настоящее время в основном за счет увеличения площади ее посева. За последние 10 лет среднегодовой ее рост составляет $13,4 \%$, урожайность в среднем по стране остается достаточно низкой - 1,57 т/га. В связи с этим обеспечение стабильного урожая высокого качества зерна сои возможно за счет совершенствования элементов технологии возделывания, и в частности оптимизации минерального питания в условиях орошения. В Ставропольском крае возможность оптимизировать минеральное питание макроэлементами $(\mathrm{N}, \mathrm{P}, \mathrm{K})$ за счёт использования минеральных удобрений при возделывании сортов сои различных групп спелости не изучали. Цель исследований -повышение урожайности и качества зерна за счёт внесения минеральных удобрений и биопрепарата при выращивании сортов сои, относящихся к различным группам спелости. Материалы и методы. Исследования проводились в 2008 - 2010 гг. на черноземе обыкновенном в зоне неустойчивого увлажнения Ставропольского края. Объектами исследований были дозы минеральных удобрений и биопрепарат (Ризоторфин), сорта сои различных групп спелости. При проведении полевых и лабораторных исследований определены урожайность и качество зерна, рассчитана экономическая эффективность изучаемых агроприемов. Уборку урожая зерна сои проводили зерноуборочным комбайном Сампо 500. Выполнение полевых и лабораторных исследований проводилось в соответствии с общепринятыми методиками: Б.А. Доспехов (1985), Ф.А. Юдин (1980), В.Н. Плешаков (1983). Для определения содержания белка и растительного жира в зерне сои использовался ядерный магнитный анализатор AMB-1006 М и ИК-анализатор MATRIX-I. Экономическая эффективность изучаемых агроприемов рассчитана с использованием технологических карт по возделыванию сельскохозяйственных культур. Результаты и обсуждение. Исследования, проведенные в условиях полевого опыта, в зоне неустойчивого увлажнения при орошении показали, что существенная прибавка урожая зерна получена при выращивании сортов сои различных групп спелости на вариантах с внесением аммофоса под основную обработку почвы в дозах $\mathrm{N}_{12} \mathrm{P}_{52}$ и $\mathrm{N}_{24} \mathrm{P}_{104}-0,13$ - 0,26, а при сочетании внесения аммофоса под основную обработку в дозах $\mathrm{N}_{12} \mathrm{P}_{52}$ и $\mathrm{N}_{24} \mathrm{P}_{104}$ и инокуляции семян Ризоторфином она была наибольшей $-0,19-0,33$ т/га. Применение биопрепарата позволило увеличить содержание белка в зерне на 0,5 - 0,8\%. Раннеспелые и среднеспелые сорта сои положительно отреагировали на применение аммофоса в дозах $\mathrm{N}_{12} \mathrm{P}_{52}$ и $\mathrm{N}_{24} \mathrm{P}_{104}$ в сочетании с инокуляцией семян Ризоторфином, содержание белка увеличилось на $0,7-1,3 \%$. На содержание растительного жира в зерне сои применяемые агроприёмы влияние не оказали. Максимальная урожайность зерна - 2,74 т/га, а также сбор белка $-0,92$ т/га и растительного жира - 0,54 т/га- получены при комплексном применении аммофоса в дозе $\mathrm{N}_{24} \mathrm{P}_{104}$ и Ризоторфинана на варианте с выращиванием среднеспелого сорта сои Селекта 302. Применение аммофоса в дозах $\mathrm{N}_{12} \mathrm{P}_{52}$ и $\mathrm{N}_{24} \mathrm{P}_{104}$ под основную обработку почвы как самостоятельно, так и в сочетании с бактериальным препаратом экономически оправдано. Лучшие экономические показатели получены на варианте с выращиванием сорта Селекта 302 и внесением аммофоса в дозе $\mathrm{N}_{12} \mathrm{P}_{52}$ в сочетании с инокуляцией перед посевом семян Ризоторфином, рентабельность составила $68,8 \%$. Выводы. В условиях зоны неустойчивого увлажнения на черноземе обыкновенном получен положительный эффект от сочетания внесения аммофоса под основную обработку в дозах $\mathrm{N}_{12} \mathrm{P}_{52}$ и $\mathrm{N}_{24} \mathrm{P}_{104}$ и инокуляции семян Ризоторфином при выращивании скороспелых, раннеспелых и среднеспелых сортов сои на орошении. Наибольшая урожайность 2,74 т/га получена при внесении аммофоса в дозе $\mathrm{N}_{24} \mathrm{P}_{104}$ и обработке семян Ризоторфином, при выращивании среднеспелого сорта Селекта 302. Лучший экономический эффект - 68,8 \% - получен при возделывании сорта Селекта 302 с внесением аммофоса в дозе $\mathrm{N}_{12} \mathrm{P}_{52}$ и инокуляцией семян Ризоторфином.

Ключевые слова:соя культурная, сорта сои, урожайность сои, Ризоторфин, среднеспелье сорта сои.

Цитирование. Шабалдас О.Г., Пимонов К.И., Есаулко А.Н., Бородычев В.В., Вайцеховская С. С. Агрохимическая и экономическая оценка применения минеральных удобрений и Ризоторфина на сортах сои различных групп спелости в условиях орошения. Известия НВ АУК. 2021. 2(62). 209-222. DOI: 10.32786/2071-9485-2021-02-22. 
Авторский вклад. Все авторы настоящего исследования принимали непосредственное участие в планировании, выполнении или анализе данного исследования. Все авторы настоящей статьи ознакомились и одобрили представленный окончательный вариант.

Конфликт интересов. Авторы заявляют об отсутствии конфликта интересов.

Введение. В последние годы в мире отмечается повышенный спрос в области производства зерна сои в связи с тем, что эта культура является одним из ведущих источников растительного белка и жира, которые служат сырьем для пищевой, кормовой и перерабатывающей промышленности $[1,4,5]$. Соя выращивается более чем в 60 странах мира. Лидерами по производству и валовому сбору соевого зерна являются США, Бразилия и Аргентина, валовой сбор зерна в которых в 2019 году составил 54-125 млн тонн. По сбору зерна сои Россия заняла 8 место среди стран мира (собрано 4,6 млн тонн). За последние 5 лет отмечен рост валового сбора зерна на 58,6\%. Однако в связи с утвержденной Министерством сельского хозяйства РФ Отраслевой Программой «Развитие производства и переработки сои в Российской Федерации на 2015-2020 годы» объемы для перерабатывающей промышленности зерна сои оказались недостаточными. Валовой сбор зерна сои растёт в основном за счет увеличения площади посева, а урожайность в среднем по стране остается достаточно низкой - 1,57 т/га $[6,7,8]$. Обеспечение качественного урожая зерна сои возможно за счет совершенствования элементов технологии выращивания, и в первую очередь оптимизации минерального питания. С учётом генетического центра происхождения и многовековых традиций возделывания, площади посева сои в основном были сосредоточены на Дальнем Востоке. За счёт интродукции наблюдается территориальное расширение выращивания культуры. Посевы сои в Центральном Федеральном округе занимают 18,1\% (Белгородская и Курская области), Южном Федеральном округе - 6,7\% (Краснодарский край), других регионах РФ площадь составляет 36,9\% от общего посева (Бородычев В.В., 2019) [3]. При возделывании сои в условиях зоны неустойчивого увлажнения в богарных условиях (Армавирская опытная станция) урожайность сортов различных групп спелости находилась в пределах от 1,12 до 2,82 т/га. В среднем за семь лет исследований в степной зоне Центрального Предкавказья, в условиях орошения, наибольшая урожайность зерна получена при выращивании сортов сои среднеспелой группы - Вилана и Селекта 302, которая составила соответственно 24,4 и 25,1 ц/га [4]. В Ставропольском крае возделывание сои возможно лишь на небольшой части территории. Это связано с тем, что основным лимитирующим фактором является дефицит влаги $[9,13,15]$. В связи с этим посевы сои лучше размещать на орошаемых участках. Соя - культура требовательная к плодородию почвы, элементы питания неравномерно поглощаются на протяжении вегетационного периода в зависимости от фазы роста и развития $[10,11,16]$. Исследователями отмечена способность использования фосфора, содержащегося в труднодоступных (трёхзамещённых) фосфатах кальция и магния. Кроме того, соя - бобовая культура, которая за счёт симбиоза с клубеньковыми бактериями использует биологический азот, поглощаемый из почвенного воздуха $[1,8,13]$. Являясь хорошим азотфиксатором, соя, по утверждению M. Sinegovskii (2018), в благоприятные по влагообеспеченности годы, может усваивать до 180-200 кг/га азота (Шабалдас О.Г., 2019) [7].

Исследования, проведенные на различных типах почвы в различных почвенноклиматических условиях, свидетельствуют о том, что вынос питательных элементов из расчета на 1 тонну зерна в среднем по различным почвенно-климатическим зонам в Российской Федерации, а также США и Франции варьирует в пределах: азота 64-95, фосфора - 10-40 и калия - 22-76 мг/кг. Продуктивность сои зависит от макро- и микроэлементов, содержащихся в почве в доступной форме в минимуме [12, 14]. 
В условиях Нижнего Поволжья Волгоградской области при орошении на светло-каштановых среднесуглинистых почвах, по утверждению В.В. Бородычёва (2015), для формирования одной тонны зерна и соответствующего количества побочной продукции, сое требуется до 80-90 азота, 30-40 фосфора, 60-65 калия и 70-80 кг кальция [2]. На содержание сырого протеина и растительного жира в зерне при дисперсионном анализе в большей степени влияет сортовой фактор. Однако применение удобрений также оказывает положительное влияние на содержание протеина и растительного жира в семенах сои, которые находятся в пределах 12,2 \% общей дисперсии содержания сырого протеина и 7,7 \% растительного жира.

Цель исследований -повышение урожайности и качества зерна за счёт внесения минеральных удобрений и биопрепарата при выращивании сортов сои, относящихся к различным группам спелости.

Материалы и методы. Закладка опытов проводилась в 2008-2010 гг. на черноземе обыкновенном в зоне неустойчивого увлажнения Ставропольского края. Орошение осуществлялось вегетационными поливами дождевальной машиной ДДА-100МА расчетной поливной нормой. В пахотном слое опытного участка содержание гумуса (по Тюрину) составляло 3,4-3,6\%, pH почвенного раствора - 8,0. Нитрификационная способность по Кравцову (в модификации Болотиной) - 20,7 мг/кг почвы. Содержание подвижного фосфора (по Мачигину) - среднее (19,7-20,6 мг/кг), обеспеченность обменным калием (по методу Кирсанова) - повышенная (295 мг/кг).

Характерной особенностью зоны неустойчивого увлажнения является наличие достаточного количества тепла и резкая континентальность. Сумма активных температур колеблется в пределах $3400-3700^{\circ} \mathrm{C}$, июль характеризуется наиболее высоким температурным режимом, температура воздуха может достигать $+38-40^{\circ} \mathrm{C}$. Среднегодовое количество осадков составляет 400-450мм, на период вегетации сои может приходиться 200-250 мм, гидротермический коэффициент равен 0,9-1,0.

Объектами исследований были дозы минеральных удобрений и биопрепарат (Ризоторфин), сорта сои различных групп спелости. Схема опыта включала следующие варианты: 1.Контроль (без удобрений и Ризоторфина). 2.Ризоторфин, 0,3 кг/га. 3. $\mathrm{N}_{12}$ (сульфат аммония). 4.N $\mathrm{N}_{12} \mathrm{P}_{52}$ (аммофос). 5.N $\mathrm{N}_{12} \mathrm{P}_{52}$ (аммофос) + Ризоторфин, 0,3 кг/га. 6. $\mathrm{N}_{24} \mathrm{P}_{104}$ (аммофос). 7. $\mathrm{N}_{24} \mathrm{P}_{104}$ (аммофос) + Ризоторфин. Изучались сорта: Лира, Селекта 101 (скороспелые), Дельта, Селекта 201 (раннеспелые), Вилана, Селекта 302 (среднеспелые).

Соя высевалась после озимой пшеницы. Удобрения вносили под вспашку (0,22-0,25 м) с последующими осенними культивациями. Весной проводились боронование зяби и предпосевная культивация (4-6 см).За 2-3 недели до посева семена сои обрабатывали фунгицидом Фундазол СП (500 г/кг) 3 кг/т, инокуляцию семян Ризоторфином (штамм 634 проводили непосредственно перед посевом. На основании ранее проведенных исследований и рекомендаций норма высева семян составляла 600 тыс. шт/га (скороспелые сорта), 550 тыс. шт/га (раннеспелые сорта) и 500 тыс. шт/га (среднеспелые сорта) [7, 8]. В борьбе с сорной растительностью по вегетирующим растениям сои (первый тройчатый лист) применялся гербицид Пивот ВК (Имазетапир 100 г/л) с нормой расхода 0,8 л/га. В период бутонизации-цветения против болезней применяли обработку растений бактофитом (2 л/га). Оросительная норма устанавливалась в зависимости от количества выпавших осадков и полевой влагоемкости почвы. Проведено 2-3 полива для скороспелых и 3-5 поливов для раннеспелых и среднеспелых сортов, общая поливная норма за вегетационный период находилась в пределах $760-2170 \mathrm{~m}^{3} /$ га.Уборку урожая зерна сои проводили зерноуборочным комбайном Сампо 500. Выполнение полевых и лабораторных исследований проводилось в соответствии с общепринятыми методиками: Б.А. Доспехова (1985), Ф.А. Юдина 


\section{***** H3BECTYY ***** \\ НИЖНЕВОАЖСКОГО АГРОУНИВЕРСИТЕТСКОГО КОМПАЕКСА:

(1980), В.Н. Плешакова (1983). Для определения содержания белка и растительного жира в зерне сои использовался ядерный магнитный анализатор AMB-1006М и ИК-анализатор MATRIX-I. (филиал ФГБНУ ФНЦ ВНИИМК). Экономическая эффективность изучаемых агроприемов рассчитана с использованием технологических карт по возделыванию сельскохозяйственных культур. Статистическая обработка полученных данных проведена с использованием программы Excel.

Результаты и обсуждение. Температурный режим и количество осадков в годы проведения исследований существенно различались. В среднем можно отметить, что вегетационный период сои в 2008 году характеризовался средней обеспеченностью осадками и температурой воздуха, практически не отличающимися от среднемноголетних показателей. 2009 год был обеспечен достаточным количеством осадков, а температурный режим находился на уровне среднемноголетних данных, 2010 год сопровождался высоким температурным режимом и острым дефицитом осадков, выпадало на $125 \%$ меньше среднемноголетней нормы.

При использовании Ризоторфина получена прибавка урожая, которая в зависимости от выращиваемого сорта составила 0,05 - 0,09 т/га (таблица 1). Внесение сульфата аммония в дозе N12 увеличивало урожайность у сортов скороспелой и раннеспелой групп на 0,06 - 0,12 т/га, для среднеспелых сортов внесение данной дозы сульфата аммония не оказывало влияния на изменение урожайности, и она находилась на уровне контроля.

Таблица 1 -Влияние применения удобрений и Ризоторфина наурожайность сортов сои, среднее за 2008-2010гг.

Table 1 - Influence of the use of fertilizers and rhizotorfin on the yield of soybean varieties, average for 2008-2010

\begin{tabular}{|c|c|c|c|c|c|c|c|}
\hline \multirow{3}{*}{$\begin{array}{c}\text { Доза удобрения/ Ризо- } \\
\text { торфин } \\
\text { (фактор B)/ Fertilizer } \\
\text { dose / Rhizotorfin } \\
\text { (factor B) }\end{array}$} & \multicolumn{6}{|c|}{ Сорт (факторА)/ Variety (factor A) } & \multirow{3}{*}{$\begin{array}{c}\text { Средняя по } \\
\text { фактору В/ } \\
\text { Average by } \\
\text { factor B }\end{array}$} \\
\hline & \multicolumn{6}{|c|}{ Урожайность, т/га/ Produktivität, t/ha } & \\
\hline & $\begin{array}{l}\text { Лира/ } \\
\text { Lira }\end{array}$ & $\begin{array}{c}\text { Селекта } \\
\text { 101/ } \\
\text { Selec- } \\
\text { ta101 }\end{array}$ & $\begin{array}{c}\text { Дель- } \\
\text { та/Delta }\end{array}$ & $\begin{array}{c}\text { Селек- } \\
\text { та201/ } \\
\text { Selecta } \\
201\end{array}$ & $\begin{array}{c}\text { Вилана/ } \\
\text { Vilana }\end{array}$ & $\begin{array}{c}\text { Селекта } \\
302 / \\
\text { Selecta } \\
302\end{array}$ & \\
\hline $\begin{array}{l}\text { Без удобр. и Ризотор- } \\
\text { фина } \\
\text { (контроль)/Withot ferti- } \\
\text { lizers. and risotorfin } \\
\text { (control) }\end{array}$ & 1,62 & 1,92 & 1,85 & 2,12 & 2,36 & 2,47 & 2,06 \\
\hline Ризоторфин/ Risotorfin & 1,68 & 1,99 & 1,91 & 2,21 & 2,42 & 2,52 & 2,13 \\
\hline $\mathrm{N}_{12}$ & 1,72 & 2,04 & 1,93 & 2,18 & 2,32 & 2,46 & 2,11 \\
\hline $\mathrm{N}_{12} \mathrm{P}_{52}$ & 1,79 & 2,07 & 2,00 & 2,28 & 2,49 & 2,60 & 2,21 \\
\hline $\begin{array}{l}\mathrm{N}_{12} \mathrm{P}_{52}+\text { Ризоторфин/ } \\
\text { Risotorfin }\end{array}$ & 1,86 & 2,14 & 2,08 & 2,40 & 2,57 & 2,68 & 2,29 \\
\hline $\mathrm{N}_{24} \mathrm{P}_{104}$ & 1,78 & 2,11 & 2,05 & 2,38 & 2,53 & 2,64 & 2,25 \\
\hline $\begin{array}{l}\mathrm{N}_{24} \mathrm{P}_{104}+\text { Ризоторфин/ } \\
\text { Risotorfin }\end{array}$ & 1,82 & 2,20 & 2,13 & 2,45 & 2,62 & 2,74 & 2,33 \\
\hline $\begin{array}{l}\text { Средняя по фактору А/ } \\
\text { Averagebyfactor A }\end{array}$ & 1,93 & 2,09 & 1,99 & 2,20 & 2,43 & 2,53 & - \\
\hline \multicolumn{8}{|c|}{$\mathrm{HCP}_{05}$ для частных средних/LSD ${ }_{05}$ for private secondary 0,17} \\
\hline \multicolumn{8}{|c|}{$\mathrm{HCP}_{05}$ по фактору A / $\mathrm{LSD}_{05}$ by factor $\mathrm{A} 0,04$} \\
\hline \multicolumn{8}{|c|}{$\mathrm{HCP}_{05}$ по фактору $\mathrm{B} / \mathrm{LSD}_{05}$ by factor $\mathrm{B} 0,07$} \\
\hline \multicolumn{8}{|c|}{$\mathrm{HCP}_{05}$ по фактору $\mathrm{AB} / \mathrm{LSD}_{05}$ by factor $\mathrm{AB} 0,17$} \\
\hline
\end{tabular}




\section{***** H3BECTYЯ ***** \\ НИЖНЕВОАЖСКОГО АГРОУНИВЕРСИТЕТСКОГО КОМПАЕКСА:

При внесении аммофоса в дозе $\mathrm{N}_{12} \mathrm{P}_{52}$ урожайность сои по сравнению с контролем была больше на 0,13-0,17 т/га, а при повышении дозы аммофоса-в два раза, до $\mathrm{N}_{24} \mathrm{P}_{104}$ - на 0,15-0,26 т/га. На вариантах с внесением аммофоса в дозах $\mathrm{N}_{12} \mathrm{P}_{52}$ и $\mathrm{N}_{24} \mathrm{P}_{104}$ и обработкой семян Ризоторфином урожайность сортов сои увеличилась на $0,21-0,28$ и 0,19 - 0,33 т/га по сравнению с контролем. В среднем за три года исследований наибольший урожай получен при выращивании среднеспелых сортов в зависимости от изучаемых доз удобрений на фоне инокуляции семян Ризоторфином, колебания составили в пределах 2,32 - 2,62 (сорт Вилана) и 2,47 - 2,74 (сорт Селекта 301) т/га.

Обработка семян Ризоторфином повлияла на содержание белка в зерне сои, которое в зависимости от сорта было выше на 0,5-0,8\% по сравнению с контролем (таблица 2). Содержание белка при внесении сульфата аммония в дозе $\mathrm{N}_{12}$ и аммофоса в дозе $\mathrm{N}_{12} \mathrm{P}_{52}$ было на уровне контроля, и находилось в пределах $36,0-38,6$ и 36,2-38,7\%. Увеличение дозы аммофоса до $\mathrm{N}_{24} \mathrm{P}_{104}$ незначительно - на 0,1-0,4\% - повышало содержание белка у раннеспелых и среднеспелых сортов сои, а скоро спелые сорта по содержанию белка находились на уровне контроля. Сочетание удобрений в дозах $\mathrm{N}_{12} \mathrm{P}_{52}$ и $\mathrm{N}_{24} \mathrm{P}_{104}$ с обработкой семян бактериальным препаратом имело наилучший эффект, содержание белка в зерне сои было больше по сравнению с контрольным вариантом на 0,5-1,3\%. На содержание растительного жира в зерне сои минеральные удобрения и Ризоторфин влияния не оказали, в среднем по сортам показатель варьировал в пределах от 20,0-22,4\%. Наибольшее содержание растительного жира отмечено у сортов Селекта 201 - от 22,0 до 22,4 и Селекта 302 - от 21,6 до 22,0\%.

Таблица 2 -Влияние применения удобрений и Ризоторфина на качество зерна сои, среднее за 2008-2010 гг.

Table 2 - Influence of the use of fertilizers and rizotorfin on the quality of soybean grain, average for 2008-2010

\begin{tabular}{|c|c|c|c|c|c|c|c|c|c|c|c|c|}
\hline \multirow[b]{3}{*}{$\begin{array}{c}\text { Доза удобрения / Ризоторфин } \\
\text { (фактор В) / } \\
\text { Fertilizer dose / Rizotorfin } \\
\text { (factor B) }\end{array}$} & \multicolumn{12}{|c|}{ Сорт (фактор A)/ Variety (factor A) } \\
\hline & \multicolumn{6}{|c|}{ белок/ squirrel } & \multicolumn{6}{|c|}{$\begin{array}{c}\text { растительный жир/ } \\
\text { vegetablefat }\end{array}$} \\
\hline & 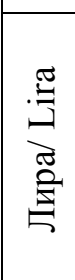 & 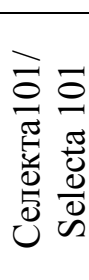 & 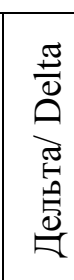 & 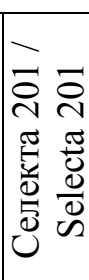 & 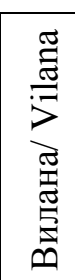 & 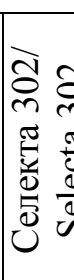 & 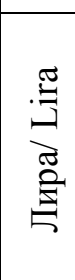 & 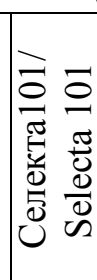 & 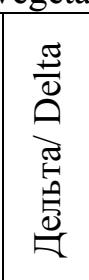 & 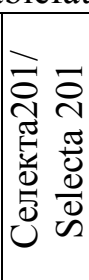 & 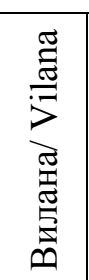 & 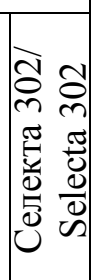 \\
\hline $\begin{array}{l}\text { Без удобр. и Ризоторфина } \\
\text { (контроль)/Withot fertilizers. } \\
\text { and Risotorfin (control) }\end{array}$ & 38,7 & 38,5 & 36,6 & 37,6 & 37,2 & 36,1 & 20,2 & 20,6 & 21,6 & 22,2 & 21,3 & 21,8 \\
\hline Ризоторфин / risotorfin & 39,2 & 39,1 & 37,2 & 38,1 & 37,9 & 36,9 & 20,3 & 20,8 & 21,8 & 22,0 & 21,0 & 22,0 \\
\hline $\mathrm{N}_{12}$ & 38,6 & 38,6 & 36,6 & 36,8 & 37,1 & 36,0 & 20,0 & 20,6 & 21,4 & 22,2 & 21,3 & 21,9 \\
\hline $\mathrm{N}_{12} \mathrm{P}_{52}$ & 38,7 & 38,6 & 36,7 & 37,7 & 37,4 & 36,2 & 20,4 & 20,5 & 21,7 & 22,2 & 21,3 & 21,6 \\
\hline $\mathrm{N}_{12} \mathrm{P}_{52}+$ Ризоторфин / Risotorfin & 39,2 & 39,1 & 37,3 & 38,4 & 38,2 & 37,3 & 20,3 & 20,5 & 21,8 & 22,3 & 21,4 & 21,7 \\
\hline $\mathrm{N}_{24} \mathrm{P}_{104}$ & 38,7 & 38,5 & 36,8 & 37,7 & 37,5 & 36,5 & 20,4 & 20,7 & 21,4 & 22,4 & 21,4 & 22,0 \\
\hline $\mathrm{N}_{24} \mathrm{P}_{104}+$ Ризоторфин / Risotor & 393 & 39.0 & 37,4 & 38.5 & 38,3 & 37.4 & 20,3 & 20.8 & 21,6 & 22,3 & 21,3 & 22,1 \\
\hline
\end{tabular}

Количество белка и растительного жира с одного гектара в зависимости от удобрений и Ризоторфина представлены на рисунках 1 и 2. Применение удобрений самостоятельно и в комплексе с обработкой семян Ризоторфином обеспечивали уве- 
личение сбора белка в среднем по изучаемым вариантам от 5,3 до 64,2\% по сравнению с контролем. У скороспелых сортов Лира и Селекта 101 сбор белка варьировал в пределах 0,59 - 0,77, раннеспелых Дельта и Селекта $201-0,61$ - 0,85 и среднеспелых Вилана и Селекта 302 - 0,79 - 0,92 т/га. При обработке семян Ризоторфином без внесения удобрений был получен наименьший эффект, прибавка в среднем по сортам составила 0,03-0,04 т/га. Внесение сульфата аммония в дозе $\mathrm{N}_{12}$ также практически не повлияло на увеличение этого показателя: так, у скороспелых сортов сбор белка был больше на 0,01-0,05 у раннеспелого сорта Дельта - на 0,02 т/га, по остальным сортам сбор белка был на уровне контроля. Внесение аммофоса в дозе $\mathrm{N}_{12} \mathrm{P}_{52}$ увеличивало сбор белка в среднем по сортам на 0,03-0,06, а при дозе $\mathrm{N}_{24} \mathrm{P}_{104}-$ на 0,06-0,09 т/га. Сочетание внесения аммофоса в дозе $\mathrm{N}_{12} \mathrm{P}_{52}$ и $\mathrm{N}_{24} \mathrm{P}_{104}$ с обработкой семян Ризоторфином обеспечило наибольший сбор белка, который в зависимости от сорта варьировал в пределах 0,08-0,13 т/га. Применение аммофоса в дозе $\mathrm{N}_{24} \mathrm{P}_{104}$ в комплексе с обработкой семян Ризоторфином способствовало максимальному сбору белка с единицы площади посева у раннеспелого сорта Селекта 201 - 0,85 и среднеспелого Селекта $302-0,92$ т/га.

Сбор растительного жира в зависимости от удобрений и бактериального препарата также отличался по вариантам. Прибавка по сбору растительного жира в зависимости от дозы удобрений, Ризоторфина и их комплексного применения, а также сорта находилась в пределах 8,8-17,2\%. Максимальный сбор растительного жира получен при внесении аммофоса в дозе $\mathrm{N}_{24} \mathrm{P}_{104}$ и обработке семян Ризоторфином сортами Селекта 101 - 0,41, Селекта 201 - 0,49 и Селекта 302 - 0,54 т/га, что больше контроля на 0,05-0,07 т/га. Скороспелыми сортами сои получен наименьший сбор растительного жира от 0,29 до 0,41 т/га, у раннеспелых сортов он был больше на 0,07-0,08 т/га, наибольший сбор белка показали среднеспелые сорта - 0,45-0,54 т/га.

Внесение удобрений и обработка семян Ризоторфином оказали определенное влияние на показатели экономической эффективности возделывания сои (таблица 3 ). С учетом затрат на производство зерна сои, в зависимости от применения удобрений и бактериального препарата, в среднем за три года, наибольшая прибыль получена при внесении под основную обработку аммофоса в дозе $\mathrm{N}_{12} \mathrm{P}_{52}$ в сочетании с обработкой семян Ризоторфином: скороспелым сортом Лира - 6631, раннеспелыми сортами Дельта и Селекта 201 - 11605-18794 и среднеспелыми сортами Вилана и Селекта 302 22638-25125 рублей с гектара, что больше контрольного варианта без применения удобрений и Ризоторфина на 1775; 1558; 2642; 1107; 1106 рублей с гектара соответственно вышеперечисленных сортов.

Уровень рентабельности в данном варианте был также наиболее высоким и составлял 18,3 (Лира), 32,0 (Дельта), 51,6 (Селекта 201), 62,1 (Вилана) и 68,8\% (Селекта 302). Скороспелым сортом Селекта 101 также получены высокая прибыль и уровень рентабельности при внесении под основную обработку аммофоса в дозе $\mathrm{N}_{12} \mathrm{P}_{52}$ в сочетании с обработкой семян Ризоторфином - 12962 рублей с гектара и $35,7 \%$, однако при внесении сульфата аммония в дозе $\mathrm{N}_{12}$ прибыль была больше по сравнению с данным сочетанием на 35 тыс. рублей с гектара, а себестоимость больше на 2,5\%. В результате анализа полученных данных установлено, что максимальный экономический эффект получен в виде прибыли - 22 638-25125 рублей с гектара среднеспелыми сортами Вилана и Селекта 302. 


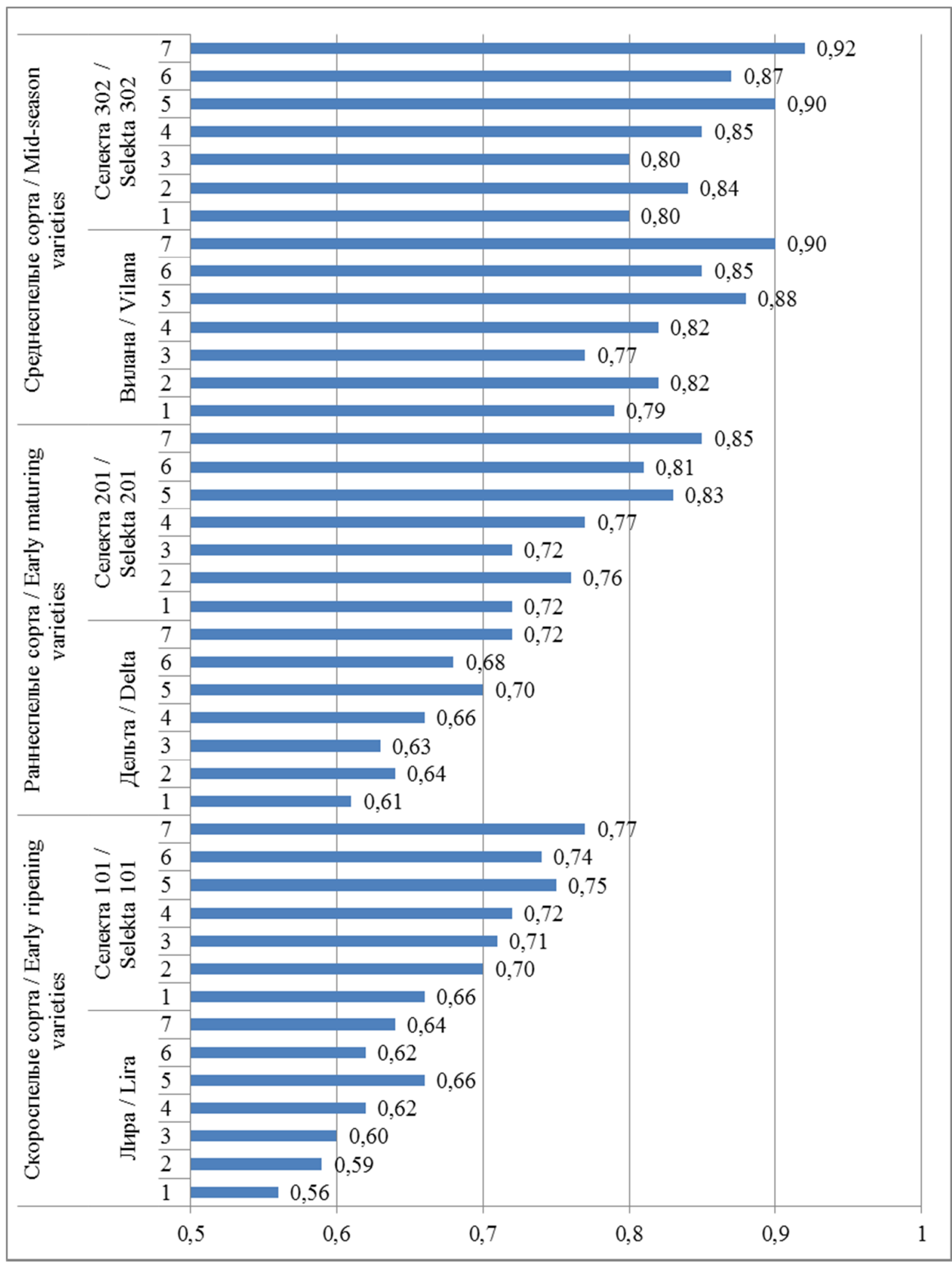

Рисунок 1 - Сбор белка в зависимости от применения удобрений и Ризоторфина, т/га (среднее за 2008-2010 гг.)

Figure 1 - Protein collection depending on the use of fertilizers andRizotorfin, $\mathrm{t} / \mathrm{ha}$ (average for 2008-2010) 


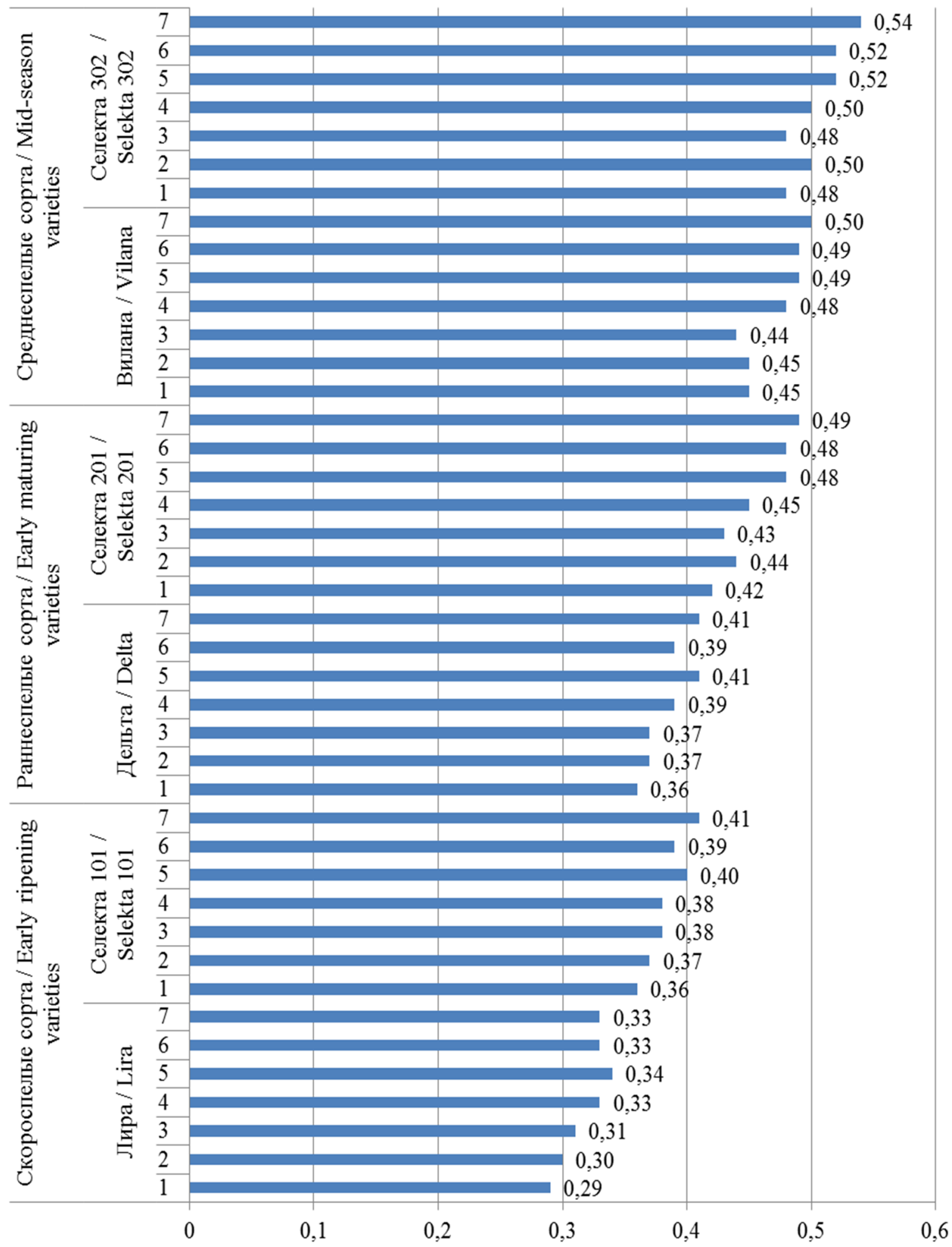

Рисунок 2 - Сбор растительного жира в зависимости от применения удобрений и Ризоторфина, т/га (среднее за 2008-2010 гг.)

Figure 2 - Collection of vegetable fat depending on the use of fertilizers andRizotorfin, $\mathrm{t} / \mathrm{ha}$ (average for 2008-2010) 


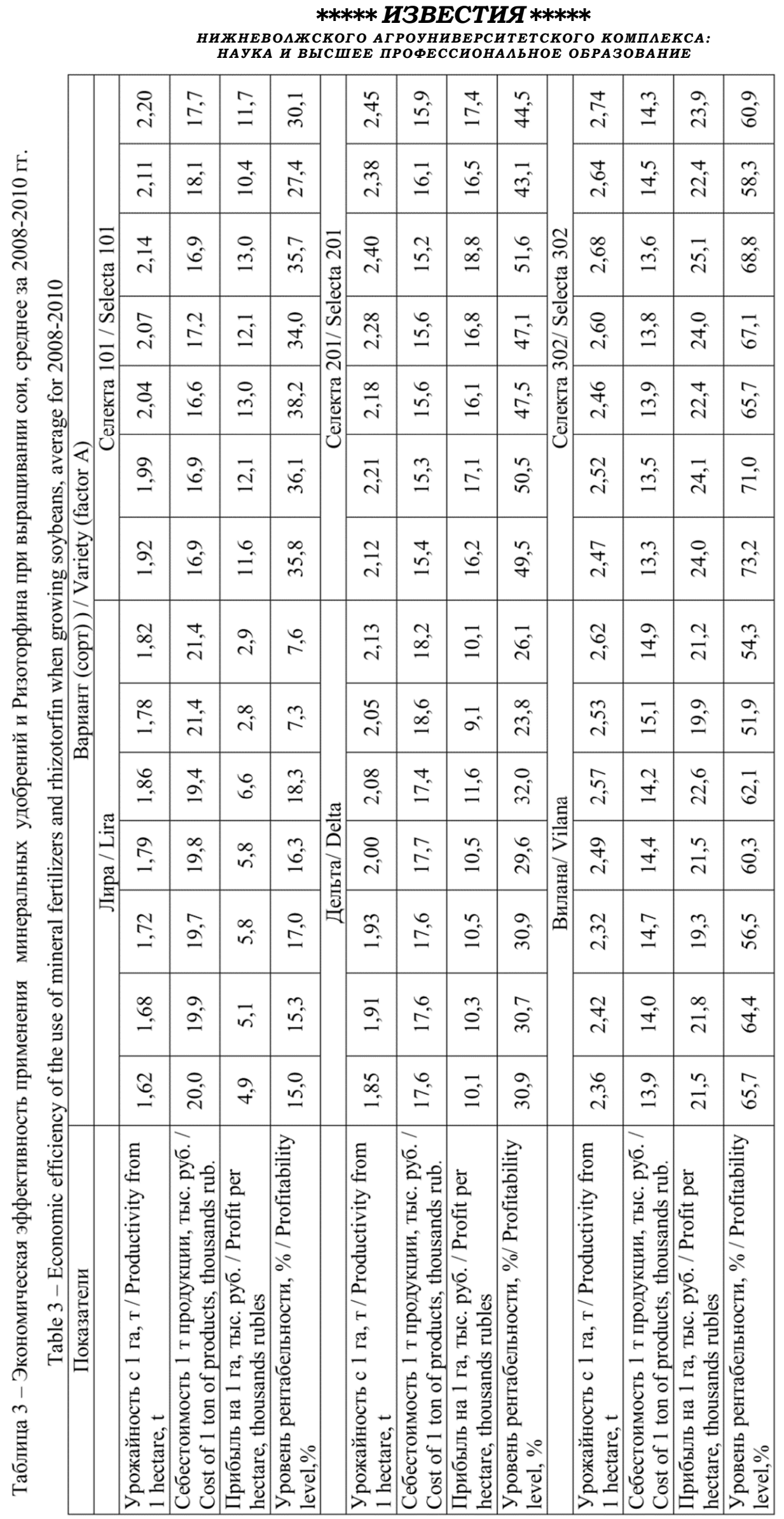


Выводы. В условиях зоны неустойчивого увлажнения на черноземе обыкновенном получен положительный эффект от сочетания внесения аммофоса под основную обработку в дозах $\mathrm{N}_{12} \mathrm{P}_{52}$ и $\mathrm{N}_{24} \mathrm{P}_{104}$ и инокуляции семян Ризоторфином при выращивании скороспелых, раннеспелых и среднеспелых сортов сои на орошении. Максимальная урожайность получена при внесении аммофоса в дозе $\mathrm{N}_{24} \mathrm{P}_{104}$ и обработке семян Ризоторфином среднеспелым сортом Селекта 302 - 2,74 т/га, наиболее высокий экономический эффект получен при возделывании сорта Селекта 302 с внесением аммофоса в дозе $\mathrm{N}_{12} \mathrm{P}_{52}$ и обработке Ризоторфином - 68,8\%.

\section{Библиографический список}

1. Балакай Г. Т., Селицкий С. А. Урожайность сортов сои при поливе дождеванием и системами капельного орошения в условиях Ростовской области // Научный журнал Российского НИИ проблем мелиорации. 2019.№ 3 (35). С. 80-97.

2. Бородычев В.В., Лытов М.Н. Особенности применения минеральных удобрений при возделывании сои при орошении в условиях нижнего Поволжья // Плодородие. 2015.№1(82). С. 33-35.

3. Бородычев В.В., Магомедова Д.С., Лытов М.Н. Агротехнические факторы эффективного использования водных ресурсов при возделывании орошаемой сои//Проблемы развития АПК региона. 2019. № 2 (38). С. 35-42.

4. Дубенок Н.Н., Бородычев В.В., Лытов М. Н. Формирование бездифицитного баланса азота в почве при возделывании бобовых культур // Агрохимический вестник. 2007. № 5. С. 9-11.

5. Кривошлыков К.М., Рощина Е.Ю., Козлова С.А. Анализ состояния и развития производства сои в мире и России //Масличные культуры. Научно-технический бюллетень Всероссийского научно-исследовательского института масличных культур. 2016. Вып 3. (167) С.64-69.

6. Лытов М.Н. Особенности формирования водного режима почвы при разных уровнях водообеспечения сои в условиях орошения // Научный журнал Российского НИИ проблем мелиорации. 2019. № 3 (35). С. 31-49.

7. Продуктивность сортов сои различных групп спелости в условиях восточной зоны Краснодарского края /О. Г. Шабалдас, Н. И. Зайцев, К. И. Пимонов [и др.]// Земледелие. 2019. № 7. C. 38-40.

8. Пути усовершенствования элементов технологии возделывания сои // Г.Т. Балакай, Л.М. Докучаева, Р.Е. Юркова, С.А. Селицкий // Научный журнал Российского НИИ проблем мелиорации. 2019. № 4 (36). С. 100-120.

9. Borodychev V. V., Lytov M. N. Irrigation management model based on soil moisture distribution profile // IOP Conf. Series: Earth and Environmental Science. 2020.V. 577. №012022.

10. Borodychev V. V., Buber A. A., DobrachevY. P. Calculation features of evaporation from the agrocoenosis soil surface at drip irrigation and fine dispersion sprinkling // IOP Conf. Series: Earth and Environmental Science. 2020. V. 577. №012003.

11. Current status of the soybean industry and research in the Russian Federation / M. Sinegovskii, S. H. Yuan, V. Sinegovskaya, T. Han //Soybean science and technology. 2018. V. 37. № 1. P. 1-7.

12. Effizienz der anwendung von mikrobiologis chenarz neimitteln auf soja samen/ I.M. Hanieva, A.L. Boziev, I.H. Tlostanov, M.V. Gesheva //Проблемы научной мысли. 2019. T. 10. №3. С. 44-48.

13. Optimum control model of soil water regime under irrigation / A. S. Ovchinnikov [et al.] // Bulgarian Journal of Agricultural Science. 2018. V. 24. № 5. P. 909-913.

14. Shabaldas O.G., Golub A. S., Mukhina O. V. Nitrogen-fixing activity of soybean plants in the application of complex inlays seeds//Research Journal of Pharmaceutical, Biological and Chemical Sciences. 2016. V. 7. № 3. P. 2348-2350.

15. Soy cultivation technology with gravity drip irrigation in south and southeast Kazakhstan / R. Yelnazarkyzy [et al.] // Journal of Ecological Engineering. 2019. V. 20. № 7. P. 39-44.

16. The effect of fertilizer system on soybean productivity in conditions of right bank foreststeppe / I. M. Didur[et all] // Ukrainian Journal of Ecology. 2019. № 9(1). P. 76-80.

Conclusions. In the conditions of the zone of unstable moisture on ordinary chernozem, a positive effect was obtained from the combination of the introduction of ammophos under the main treatment in doses of N12P52 and N24P104 and inoculation of seeds with Rhizotorphin 
when growing precocious, early-ripening and medium-ripening soybean varieties under irrigation. The maximum yield was obtained when applying ammophos at a dose of N24P104 and treating seeds with Rhizotorphin with a medium-ripened variety of Select 302-2.74 t / ha, the highest economic effect was obtained when cultivating the variety of Select 302 with the introduction of ammophos at a dose of N12P52 and processing with Rhizotorphin-68.8\%.

\section{Reference}

1. Balakai G. T., Selitsky S. A. The yield of soybean varieties when watering with sprinkling and drip irrigation systems in the conditions of the Rostov region / / Scientific Journal of the Russian Research Institute of Problems of Melioration. 2019. No. 3 (35). pp. 80-97.

2. Borodychev V. V., Lytov M. N. Features of the use of mineral fertilizers in the cultivation of soybeans under irrigation in the conditions of the lower Volga region // Fertility. 2015. No. 1(82). pp. 33-35.

3. Borodychev V. V., Magomedova D. S., Lytov M. N. Agrotechnical factors of effective use of water resources in the cultivation of irrigated soybeans//Problems of the development of the agroindustrial complex of the region. 2019. No. 2 (38). pp. 35-42.

4. Dubenok N. N., Borodychev V. V., Lytov M. N. Formation of a non-deficit balance of nitrogen in the soil during the cultivation of legumes. 2007. No. 5. pp. 9-11.

5. Krivoshlykov K. M., Roshchina E. Yu., Kozlova S. A. Analysis of the state and development of soybean production in the world and Russia //Oilseeds. Scientific and technical Bulletin of the All-Russian Research Institute of Oilseeds. 2016. Issue 3. (167) p

. 64-69. 6. Lytov M. N. Features of the formation of the water regime of the soil at different levels of water supply of soybeans in irrigation conditions // Scientific Journal of the Russian Research Institute of Land Reclamation Problems. 2019. No. 3 (35). pp. 31-49.

7. Productivity of soybean varieties of different maturity groups in the conditions of the eastern zone of the Krasnodar Territory /O. G. Shabaldas, N. I. Zaitsev, K. I. Pimonov [et al.] / / Agriculture. 2019. No. 7. pp. 38-40.

8. Ways of improving the elements of soybean cultivation technology / / G. T. Balakai, L. M. Dokuchaeva, R. E. Yurkova, S. A. Selitsky / / Scientific Journal of the Russian Research Institute of Land Reclamation Problems. 2019. No. 4 (36). pp. 100-120.

9. Borodychev V. V., Lytov M. N. Irrigation management model based on soil moisture distribution profile // IOP Conf. Series: Earth and Environmental Science. 2020.V. 577. №012022.

10. Borodychev V. V., Buber A. A., DobrachevY. P. Calculation features of evaporation from the agrocoenosis soil surface at drip irrigation and fine dispersion sprinkling // IOP Conf. Series: Earth and Environmental Science. 2020. V. 577. №012003.

11. Current status of the soybean industry and research in the Russian Federation / M. Sinegovskii, S. H. Yuan, V. Sinegovskaya, T. Han //Soybean science and technology. 2018. V. 37. № 1. P. 1-7.

12. Effizienz der anwendung von mikrobiologis chenarz neimitteln auf soja samen/ I.M. Hanieva, A.L. Boziev, I.H. Tlostanov, M.V. Gesheva //Problems of scientific thought. 2019. Vol. 10. no. 3. pp. 44-48.

13. Optimum control model of soil water regime under irrigation / A. S. Ovchinnikov [et al.] / / Bulgarian Journal of Agricultural Science. 2018. V. 24. № 5. P. 909-913.

14. Shabaldas O.G., Golub A. S., Mukhina O. V. Nitrogen-fixing activity of soybean plants in the application of complex inlays seeds//Research Journal of Pharmaceutical, Biological and Chemical Sciences. 2016. V. 7. № 3. P. 2348-2350.

15. Soy cultivation technology with gravity drip irrigation in south and southeast Kazakhstan / R. Yelnazarkyzy [et al.] // Journal of Ecological Engineering. 2019. V. 20. № 7. P. 39-44.

16. The effect of fertilizer system on soybean productivity in conditions of right bank foreststeppe / I. M. Didur[et all] // Ukrainian Journal of Ecology. 2019. № 9(1). P. 76-80.

\section{Authors Information}

Shabaldas Olga Georgievna, Associate Professor of the Department of General Agriculture, Plant Growing, Breeding and Seed Production, Stavropol State Agrarian University (Russia, 355017, Stavropol, perZootekhnichesky, 12), candidate of Agricultural Sciences, ORCID: http: // orcid. org / 0000-0001-56061855, phone: + 9097607047, e-mail: shabaldas-olga@mail.ru 


\title{
***** H3BECTKЯ ***** \\ НИЖНЕВОАЖСКОГО АГРОУНИВЕРСИТЕТСКОГО КОМПАЕКСА \\ НАУКА И ВЫСШЕЕ ПРОФЕССИОНААЬНОЕ ОБРАЗОВАНИЕ
}

Pimonov Konstantin Igorevich, Professor of the Department of Crop Production, Don State Agrarian University (Russia, 346493, Rostov region, Oktyabrsky district, p. Persianovsky, Krivoshlykova str., 24), doctor of agricultural Sciences, ORCID: http://orcid.org 0000-0003-0726-2583, phone:+79882562700, email: Konst.pimonov@yandex.ru

Esaulko Alexander Nikolaevich, Professor of the Russian Academy of Sciences, Professor of the Department of «Agrochemistry and Plant Physiology», Stavropol State Agrarian University» (Russia, 355017, Stavropol, per. Zootechnical 12), doctor of agricultural Sciences, ORCID: http://orcid.org 0000-0003-04419055, phone: +7(962)400-41-95, e-mail: aesaulko@yandex.ru

Borodychev Viktor Vladimirovich, Academician of the Russian Academy of Sciences, Director of the Volgograd Branch of the Federal State Budget Scientific Institution All-Russian Scientific Research Institute of Hydrotechnics and Land Reclamation named after A.N. Kostyakova (400002, Volgograd, Timiryazev St., 9), Doctor of Agricultural Sciences, Professor.

ORCID: https://orcid.org/0000-0002-0279-8090. E-mail:vkovniigim@yandex.ru

Vaytsekhovskaya Svetlana Sergeevna, Associate Professor of the Department of Entrepreneurship and World Economy, Stavropol State Agrarian University (Russia, 355017, Stavropol, perZootechnical, 12), candidate of economic sciences, ORCID: http://orcid.org/0000-0003-0147-2942, phone.:+79187446612, email:FantasiaSM@mail.ru

\section{Информация об авторах}

Шабалдас Ольга Георгиевна, доцент кафедры общего земледелия, растениеводства, селекции и семеноводства ФГБОУ ВО«Ставропольский государственный аграрный университет» (РФ,355017, г.Ставрополь, пер. Зоотехнический, 12), кандидат сельскохозяйственных наук, ORCID:http://orcid.org/0000-0001-5606-1855, тел.:+9097607047,e-mail:shabaldas-olga@mail.ru

Пимонов Константин Игоревич, профессор кафедры «Растениеводство», ФГБОУ ВО «Донской государственный аграрный университет» (РФ, 346493, Ростовская обл., Октябрьский район, п. Персиановский, ул. Кривошлыкова, 24), доктор сельскохозяйственных наук, ORCID: http://orcid.org0000-0003-0726-2583, тел.:+79882562700,e-mail: konst.pimonov@yandex.ru

Есаулко Александр Николаевич, профессор РАН, профессор кафедры «Агрохимии и физиологии растений», ФГБОУ ВО «Ставропольский государственный аграрный университет» (РФ, 355017, г. Ставрополь, пер. Зоотехнический 12), доктор сельскохозяйственных наук, ORCID: http://orcid.org0000-0003-0441-9055.тел.:+7(962)400-41-95,e-mail: aesaulko@yandex.ru

Бородычев Виктор Владимирович, академик РАН, директор Волгоградского филиала федерального государственного бюджетного научного учреждения Всероссийский научноисследовательский институт гидротехники и мелиорации им. А.Н. Костякова (400002, г. Волгоград, ул. Тимирязева, 9), доктор сельскохозяйственных наук, профессор.

ORCID: https:// orcid.org/0000-0002-0279-8090. e-mail: vkovniigim@yandex.ru

Вайцеховская Светлана Сергеевна, доцент кафедры предпринимательства и мировой экономики, ФГБОУ ВО «Ставропольский государственный аграрный университет»(РФ,355017, г. Ставрополь, пер. Зоотехнический, 12), кандидат экономических наук,

ORCID: http:/orcid.org/0000-0003-0147-2942, тел.:+79187446612,e-mail: FantasiaSM@mail.ru

\section{EVALUATION AND SELECTION OF COLLECTION SAMPLES OF WATERMELON FOR USE IN THE BREEDING PROCESS}

\author{
E.A. Varivoda ${ }^{1}$, T.G. Koleboshina ${ }^{1}$, S. D. Fomin ${ }^{2}$, E.S. Maslennikova ${ }^{1}$ \\ ${ }^{1}$ Bykovskaya Melon Selection Experimental Station - a branch of the Federal Scientific Center \\ for Vegetable Growing, Volgograd \\ ${ }^{2}$ Volgograd State Agrarian University, Volgograd
}

Received 03.04.2021

Submitted 28.05.2021

\section{Abstract}

Introduction. Melon growing is considered one of the profitable areas of agriculture. One of the problems in the industry is low yields. Expansion of the assortment due to the introduction into production of new high-yielding varieties and hybrids of melons and gourds will allow increasing the yield by 15$20 \%$ without additional costs. To solve this problem, it is necessary to select the source material that meets the requirements of modern breeding. The purpose of this work is to study the diversity of col- 